Зорица П. ХАЏИТ

Универзитет у Новом Саду

Филозофски факултет
Оригинални научни рад

Примљен: 28. 10. 2020.

Прихваћен: 25. 2. 2021.

\title{
(АУТО)БИОГРАФСКИ ЕЛЕМЕНТИ У ДЕЛУ МИЛАНА КАШАНИНА ${ }^{* *}$
}

\begin{abstract}
Милан Кашанин је на више места истицао да је од суштинске важности познавати живот аутора да би се ваљано могло протумачити његово дело. Предмет истраживања у раду су књиге Сусрети и писма (1974), Случајна открића (1977) и роман Привиђења (1981). Кашанин је, нудећи читаоцима фрагменте аутобиографског у сопственом књижевном делу, на суптилан начин успео да аутобиографске елементе не пружи читаоцима у експлицитној форми, него да их икористи као књижевну грађу.

Кључне речи: фикција, факт, аутобиографија, живот, књижевност.
\end{abstract}

У разговору са Костом Димитријевићем 1975. године, на питање о томе да ли и он, попут Андрића, сматра да биографија писца нема никакве везе са пишчевим делом, Кашанин је одлучно и одречно одговорио: „То је сасвим погрешно гледање на живот и ствари, јер се тиме кукавички бежи од стварности. Ја сам доста својих прозних текстова посветио описима савремености, па због тога доживљавао и неприлике услед распознавања" (Димитријевић 2015: 12). ${ }^{1}$

Дакле, могло би се из овог одговора недвосмислено закључити да приликом размишљања о односу живота и литературе, Кашанин иде у ред оних стваралаца који сматрају да ће „проучавање живота дела и писаца бити неодвојиво докле је света и века" (Димитријевић 2015: 14) и инсистирају на томе да је књижевно дело прожето макар фрагментима из пишчевог живота. Изречен став Милан Кашанин је поновио неколико пута, на различитим местима и приликама, дајући му тако на важности и значају.

Андрићево и Кашаниново размишљање о вези пишчевог живота и дела било је дијаметрално супротно. Андрић је доследно изражавао отпор према

*zorica_hadzic@ff.uns.ac.rs

** Рад је настао као део научног пројекта 178005, чији је руководилац проф. др Светлана Томин, а који финансира Министарство просвете, науке и технолошког развоја Републике Србије.

${ }^{1}$ Разговор је вођен поводом обележавања пола века књижевног рада Милана Кашанина. 
аутобиографији: „Писац треба да пише и прича, али не да од свог живота ствара причу” (Андрић 2000: 259). Кашанин је другачије резоновао: „И док је жив и, још више, кад га нема, један писац и један уметник није само творац својих дела, него и личност за приповетку” (Кашанин 1974: 6); „А мој живот, као и већине наших писаца, даје захвалну грађу за приповетку или роман, јер сам прошао кроз многе буре, окршаје и невоље, доспевао до великих части, признања, али и понижења, дружио се са сиротим барањским сељацима и био радо приман од највећих уметника света, познатих краљева и кнежева...” (Димитријевић 2015: 13).

Иако је наш нобеловац проглашавао везу између пишчевог живота и дела излишном, показало се, да је ипак реч о суштински амбивалентном односу према аутобиографији, те да Андрић често „противречи сопственом схватању о ирелевантности пишчевог живота у покушају разумевања његовог дела" (Перишић Ђукић, 2012: 18)². Са друге стране, Милан Кашанин је, видели смо, сматрао везу између књижевног дела и живота писца неодвојивом. У трагању за аутобиографским елементима у делу Милана Кашанина, показаће се да ли је и колико је он „бежао” од биографије односно у којој мери је од фрагмената сопствене и биографије својих савременика обликовао литерарне јунаке.

За разлику од Андрића, Кашанин, није имао отпор према објављивању сопствене преписке и писању дневника, поступку који свакако разголићује аутора пред читалачком публиком. (И Андрић је, показано је, водио дневничке белешке). Ипак, изречени ставови Милана Кашанина узети без резерве, неретко су бацали сенку на његово дело. Заклањали су књижевни текст, дајући за право критичарима, вођеним инерцијом, да писца прогласе за конзервативног и превазиђеног. Кашанин, ипак, није написао аутобиографију. Није му пошло за руком ни да пронађе сопственог Екермана који би забележио његова богата и разноврсна сећања (Оцић 2004: 229). Преостаје, дакле, да поставимо питање да ли и колико има аутобиографских детаља у текстовима и књигама његовог опуса. На појединачним примерима истражићемо аутобиографске елементе, свесни да нећемо понудити коначан одговор о њиховој свеукупности у Кашаниновој прози.

Уколико се вратимо у прошлост, у време између два рата, можемо да приметимо да се однос Милана Кашанина према аутобиографском у сопственом делу мењао и модификовао. ${ }^{3}$ Још као младић, он је у писму композитору Петру Коњовићу, у вези са романом Лаж (касније Пијана земља) тврдио да: „Аутобиографског у роману нема ничег, јер нећу да стварам себе од папира, него да изнесем живе људе” (Кашанин 1974: 222). Међутим, јасно je, судећи по ономе што је у позним годинама говорио, да се и ова тврдња може довести у питање. Најзад, у роману Пијана земља препознаје се (ауто) биографско, али пре као колективно него индивидуално, дато кроз оптику

\footnotetext{
2 У том смислу значајно је имати у виду и рад Јелене Новаковић „Однос према аутобиографији или 'мрско ја': Иво Андрић и француска књижевна мисао” (Новаковић 1998: 299-309).

${ }^{3}$ У овом тексту није разматрана међуратна проза Милана Кашанина, иако се и то указује као занимљива тема.
} 
младог нараштаја чија је крила сломио рат. Када већ говоримо о међуратном периоду, занимљиво је да је Кашанин јунаке своје прозе неретко обликовао према стварним личностима попут Анице Савић Ребац (Удовички 1982: 26) или његовог гимназијског професора Милана Петровића. Уосталом, и сам је говорио да у његовим приповеткама „нема ниједне личности а да није постојала у животу" (Недић 2004: 246) и да су оне које је измислио - неуспеле. На истом месту, открио је на који начин живе моделе транспонује у својој прози: „Нешто се мора изменити, изварирати” (Недић 2004: 246).

Приређујући између два рата Сабрана дела Јована Грчића Миленка и пишући предговор том издању, Кашанин је трагао за подацима из живота овог рано преминулог писца. Нарочито су га интересовали „иконографски” детаљи: лични предмети писца, књиге из његове библиотеке, фотографије, породични портрети... ${ }^{4}$ Познато је, такође, да је Кашанин истоветан истраживачки поступак применио приређујући за штампу Дневник Лазе Костића. И тада је изричито држао до повезаности пишчевог живота са делом, интересујући се за детаље из живота великог романтичара: „За разумевање једног песника од примордијалне важности је познавање историје и друштвене атмосфере у којој се он кретао - људи са којима се дружио, жена које је волео, кућа у којима је становао, предела кроз које се кретао" (Кашанин 2000: 93).

На овом месту скренућемо пажњу на продор аутобиографских елемената у прозном опусу Милана Кашанина насталом након Другог светског рата. У нашем видокругу биће књиге Сусрети и писма (1974), Случајна открића (1977) и роман Привиђења (1981). Све три књиге су позни изданци пишчевог књижевног стварања где се на једној страни налазе као представници хибридних жанрова Сусрети и писма и Случајна открића, а на другој фикционална проза, недовршен роман Привиђења. Прве две књиге написане су као мешавина мемоарског, аутобиографског, путописног и критичког дискурса.

Може се делом, у овом кључу, посматрати и књига бриљантне есејистике Судбине и људи (1968), где су у есејима о Лази Костићу, Ђури Јакшићу и Богдану Поповићу на извесним местима уткани детаљи из личног искуства. Тако ће есеј „Прометеј” започети пишчевим сећањем на сусрет са Лазом Костићем у Новом Саду: „Ишао сам с једним другом из новосадске гимназије у шетњу око града Варадина, одакле се, ваљда, он враћао, јер смо се срели у Дунавској улици. Било је лето, улице празне, он велик. Мој друг и ја смо га поздравили, али нас он није видео (Кашанин 1968: 66). Есеј „Мученик”, посвећен Ђури Јакшићу, Кашанина ће подстаћи да се сети новосадске кафане „Код Камиле”, знаменитог места окупљања романтичара: „Има нас који још памтимо ту 'Камилу', дугу приземну зградурину са ниско стављеним прозорима, преко пута пожутеле и вечито закључане унијатске цркве - у улици која је за људског века толико пута мењала име да више нико не зна како се зове - и носимо о њој неизбрисиво осећање туге (Кашанин 1968: 36).

\footnotetext{
${ }^{4}$ О томе сведочи преписка Милана Кашанина са сродницима породице Јована Грчића Миленка.

${ }^{5}$ О Кашаниновом интересовању за детаље из живота Лазе Костића сведочи његова преписка са Миланом Коњовићем и Тривом Милитаром.
} 
У потрази за детаљима Кашанинове аутобиографије издвајају се Случајна открића као његова најличнија и најинтимнија књига, састављена од осамнаест „кратких исповедних прича” како их је писац именовао у писму Бошку Петровићу (РОМС, инв. бр. 48. 081). Интересантно је да се ова књига, у појединим сегментима, ослања на пишчев необјављени дневник, писан на путовању у Француску, Америку и Канаду од 3. јануара до 17. фебруара 1963. године (РОМС, Лични фонд „Милан Кашанин”, у обради). Поређењем дневничког текста и цртица објављених у књизи Случајна открића јасно је да је Кашанин одређене мисли и осећања из дневника транспоновао у своје исповедне приче. Тако је, на пример, први дневнички запис од 3. јануара 1963. године инкорпориран у кратку причу „Лет и смрт”, уз минималне модификације:

Дневнички запис: „Пошао од куће у Београду по мраку и зими јутрос у $6^{10}$, са Љаљом и Павлом. Ма како се радовао путу - овоме много нисам - увек ми, и сад, остарелом, као и кад сам био дете, жао што се растајем. Аутобусом, до аеродрома, пратила ме само Љаља - жена једино прати човека. Без много речи сачекали да се раздвојимо, јер се на узлетиште не пушта нико сем путника. Гледала ме једно време кроз стакло које нас је раздвајало, - тако ће нас једном смрт раздвојити: да одлазимо на разне стране, а увек ишли заједно” (РОМС, Лични фонд „Милан Кашанин”, у обради).

Случајна открића: „Пошао сам од куће у рано јутро, по мраку и зими, радујући се што путујем и жалећи што одлазим. До аеродрома пратила ме само жена, - у животу само жена прати човека. Без много речи смо се опростили и још једном се погледали кроз мукло стакло које у чекаоници одваја оне што одлазе од оних што остају. Тако ће нас једном и смрт раздвојити отићи ћемо на разне стране, а увек смо ишли заједно" (Кашанин 1977: 69).

Случајна открића јесу књига у којој је, добро и вешто нађен баланс између пишчевих рефлексија о животу, стварању и аутобиографских момената. У оквиру ових записа Кашанин спорадично открива детаље из биографије, који јесу повод, али не нужно и циљ приповедања. Он се на страницама Случајних открића сећа детаља и атмосфере свог одрастања, младости и пословних подухвата.

У нешто другачијем кључу, из другачије визуре, исписана је књига $C y$ срети и писма. Пишући о савременицима, Кашанин неминовно исписује својеврсну „аутобиографију о другима” остављајући читаоцима податке из сопственог животописа. У десет целина, Кашанин доноси портрете својих пријатеља и сарадника (А. Савић Ребац, И. Секулић, М. Јакшића, Ј. Дучића, П. Слијепчевића, И. Мештровића, Т. Росандића, П. Коњовића, М. Миловановића и С. Шумановића). У сваком портрету препознајемо аутобиографске и мемоарске пасаже који се, највећим делом, односе на године између два рата. Тако се Кашанин у портретима Анице Савић Ребац и Петра Коњовића опомиње својих гимназијских дана проведених у Новом Саду где их је први пут угледао. Део записа о Коњовићу посвећен је и годинама Првог светског рата у Загребу. У портретима Ивана Мештровића, Милана Миловановића, Томе Росандића и Саве Шумановића, Кашанин, неизоставно, мора да проговори 
и о себи, јер је њихова сарадња била везана за Кашанинов рад у Уметничкој школи, као и формирање Музеја савремене уметности односно Музеја кнеза Павла. Док пише о Дучићу, Кашанин се са симпатијама сећа времена проведеног у Холандији, сарадње са издавачким предузећем „Народна просвета", оснивања Музеја и покретања часописа Уметнички преглед. Портрет Исидоре Секулић открива детаље о томе како је Кашанин објавио прву приповетку у Српском књижевном гласнику, као и његово учешће у књижевном и културном животу између два рата. Писац у овој књизи налази идеалан баланс између проживљеног искуства и уметнички обликованог портрета, остављајући читаоцима не само успеле портрете савременика и оцене њиховог дела него и фрагменте сопствене аутобиографије.

Примећујемо, ипак, да је Кашанин, због специфичног историјског мизансцена, бирао да у наведеним књигама селективно износи детаље из живота. Невољно и штуро се задржавао на темама и догађајима због којих је био прокажен после Другог светског рата, иако је и за такве реминисценције било простора. ${ }^{6}$ Стога не може много ни да чуди што о одређеним темама није ни писао ни говорио. Чак је та стална пишчева потреба за дистанцирањем ишла до те мере да ни на једном месту није забележио, ни јавно рекао, како је, за време окупације, сачувао Мирослављево јеванђеље, о чему се нешто више сазнало тек захваљујући писању Дејана Медаковића.

Када је реч о присуству аутобиографских елемената у делу Милана Кашанина, не може да се не спомене роман Привиђења. За разлику од књига о којима смо говорили, реч је о фикционалној прози. Пишчев последњи роман, објављен у години његове смрти, остао је недовршен и имао ту несрећу да ни приликом појаве другог издања не буде објављен као целина. ${ }^{7}$ Специфичан је, и по томе, што Кашанин, тематизујући живот грађанског друштва у предвечерје Другог светског рата, транспонује фрагменте сопственог животног искуства градећи романескне ликове. Ти фрагменти оличени су, најпре, на фону књижевне обраде једног од главних јунака романа, историчара уметности Павла Деспинића. Кашанин му „позајмљује” детаље сопствене биографије, истовремено стварајући дистанцу између сопственог живота и животног пута свог литерарног јунака. Сличности између писца и његовог јунака уочљиве су на први поглед. Уочава се да је, као и сам писац, и његов јунак Павле Деспинић рано остао без мајке. Приповедање о Деспинићевом раном губитку мајке у одређеним нијансама има додирних тачака са цртицом „Састанак” из исповедне књиге Случајна открића:

Привиђења: „Кад би устала, колико би била млађа од свог сина!” (Кашанин 2003: 141). 1977: 52)

Случајна открића: „Моја мати је сад млађа од мене, и увек ће бити млада” (Кашанин

\footnotetext{
6 Замерано му је што је као директор Музеја кнеза Павла био близак кнежев сарадник као и то што је током окупације објавио две књиге.

${ }^{7}$ Роман је објављиван у књижевној периодици, у фрагментима, од 1954. године. Прва књига штампана је 1981. Други део романа приредио је за штампу Предраг Вукадиновић и објавио га у часопису Савременик. Поједини необјављени фрагменти романа чувају се, још увек, у рукопису.
} 
Привиђења: „На Павлову жалост (...) није било у кући ни њеног портрета: пре удаје сматрали су да је сувише млада за сликање - имала је свега шеснаест година - а после је остала трудна с једним, па с другим сином, а и њен отац је желео да је слика Паја Јовановић, који никако није стизао из Беча" (Кашанин 2003: 164).

Случајна открића: „Умрла је кад сам био толико мали да нисам могао упамтити њене црте, а били смо сиромашни и није се никад сликала” (Кашанин 1977: 51).

Beћ ce из ових навода може закључити да Кашанин прави јасну дистинкцију између аутобиографије и фикције одређујући свог јунака пореклом. Павле Деспинић, потомак угледне и богате породице, баш као и сам писац, има старијег брата. Браћа су завршила новосадску гимназију. Доживљаји из школовања браће Деспинић - и браћа Кашанин су похађала новосадску гимназију - одговарају пишчевим аутобиографским записима нађеним у његовој рукописној оставини. ${ }^{8}$ Међутим, иако ови подаци могу да заведу, било би апсолутно погрешно помислити да је лик Павла Деспинића стваран искључиво на основу детаља из пишчеве биографије. Кашанин своје ликове гради поступком који ће, како смо већ навели, прогласити као варијацију стварности. Јер, у лику Павла Деспинића препознајемо и део ратне биографије пишчевог старијег брата, чувеног математичара Радивоја Кашанина и његово ратно искуство на Добруџи и Солунском фронту.

Није неважно што је професионално опредељење Павла Деспинића истоветно са пишчевим. Обојица су историчари уметности. (Чак ће Кашанин Деспинићу „позајмити” и нека своја познанства, као на пример са угледним стручњаком из исте области, Лионелом Вентуријем.) Деспинићева занесеност Холандијом одговара Кашаниновом одушевљеном доживљају ове земље и њених уметника. Холандија се, као крипто тема у Кашаниновом опусу, препознаје и у роману Привиђењь.

Везе између писца и његовог јунака се ту не завршавају. Интересантан je, у том смислу, и простор романа. Кашанин породицу професора Деспинића смешта у стан у Улици маршала Пилсудског, где је и породица Кашанин живела до 1944. године. За разлику од писца, расејани Деспинић страћивши породично наследство, живи у изнајмљеном стану. Ако бисмо трагали за детаљима који чине простор романа, наишли бисмо на једну репродукцију на Деспинићевом радном столу. Читаоци ће запазити опис истоветне репродукције на страницама Кашанинове исповедне књиге Случајна открића и у роману Привиђења:

Привиђења: „Он [Павле Деспинић] је у својој радној соби држао на столу репродукцију, не њене слике, него неке за коју нико није знао, па ни он, шта је ни чија је. Њему и није било до слике, него до девојке у парку на клупи, на којој је десно од себе ставила књигу, а лево шешир" (Кашанин 2003: 20).

Случајна открића: „Држао сам и другу [репродукцију] - слику девојке која седи на клупи у парку и, са шеширом у руци, неког чека" (Кашанин 1977: 22).

Колико простор романа толико су мисли и сколоности Павла Деспинића често блиске Кашаниновим резоновањима (Тријић 2018: 129-130).

\footnotetext{
${ }^{8}$ На пример, о посетама гимназијалаца новосадском позоришту (Кашанин 2003: 159).
} 
Најзад, није само лик Павла Деспинића и простор који га окружује подстицајан за овакво читање, нити се наша тема овде исцрпљује. Мора се имати у виду да Кашанин и његов јунак имају више разлике него сличности, што је очигледно праћењем даљег развоја и судбине Деспинићевог лика. Међутим, поред Павла Деспинића, и за формирање осталих ликова Кашанин је користио детаље сопственог животног искуства. До овог закључка долазимо након читања необјављених записа из његове рукописне оставине о писцима и уметницима које је познавао. Наиме, Кашанин је у својим хартијама оставио неуобличене и незавршене белешке о Милошу Црњанском, Растку Петровићу, Тодору Манојловићу, Павлу Бељанском, Слободану Јовановићу, Богдану Поповићу, кнезу Павлу Карађорђевићу и другима (РОМС, Лични фонд „Милан Кашанин”, у обради). Детаље из ових записа, пишчеве утиске, препознајемо на страницама романа Привиђењ $а$. Тако се могу наслутити које су личности биле прототипови приликом Кашаниновог обликовања појединих романескних јунака. Писац је својим јунацима позајмљивао понешто од стварних судбина и карактера његових савременика, тако да међу приказаним припадницима београдског књижевног, политичког и културног круга између два рата препознајемо и конкретне личности. Тако Кашанинов јунак Драгослав Којић, књижевник и књижевни саветник Деспинићеве супруге Рушке, снобовски оријентисане књижевнице у покушају, има у себи нешто од наших модерниста. Добро је обавештен о француској књижевности, пише манифесте, жели да путује у Африку и пише студије о црначкој скулптури и путописе о језеру Чаду. Са друге стране, у лику каријеристе Винка Бабића позајмљено је и транспоновано нешто од Кашаниновог доживљаја Иве Андрића. Доцент Винко Бабић загонетан је за београдске староседеоце, из Босне, учио у Сарајеву, Загребу и Кракову, ћутљив и затворен, нежења, каријериста, уздржан, заинтересовани слушач о зулумима босанских Турака, питају се у друштву да ли је Србин или Хрват, воли да посећује куће у којима има девојака на удају или није му стран живот у „брачном троуглу” (Кашанин 2003: 82-83).

Интересантан је, приликом тражења аутобиографских елемената, лик професора Коче Пантуле. Још када се одломак „Ујка”, посвећен Кочи Пантули, појавио у периодици, међу савременицима су се јавиле бројне асоцијације на могућна Кашанинова полазишта у грађењу лика овог универзитетског професора. Тако је по појави овога одломка у београдској Кюижевности, Кашанину писао Милан Лазаревић 1955. године: „Ваш Пантула није само Цинцарин по презимену и пореклу него један од многих 'научних радника' који није напустио паланачки ћифтанлук, халапљивост и вечити страх од глади. Није искључено да је Пантула Станоје Станојевић или Јован Радонић или неки од многобројних и увек гладних професора и академика који се стално врзмали око 'специјалних' додатака, хонорара, комисија итд” (РОМС, Лични фонд „Милан Кашанин”, у обради).

Најближе истини јесте да је лик Коче Пантуле настао као синтеза неколико, у то време, угледних професорских имена. Ипак, као доминантни прототип за грађење његовог лика издваја се универзитетски професор 
Богдан Поповић. Академик и професор Коча Пантула чак је и физички сличан Поповићу - омањи је и црнпураст. Коча Пантула је приказан у пару са браћом, такође нежењама, Димитријем и Марком, од којих је он најугледнији и најцењенији у друштву. Пантуле, као и браћа Поповић, потичу из старе и угледне породице. Коча Пантула свира виолину и чува сервис који је на поклон добио од краљице Драге што је, опет, јасно поигравање са детаљима из Поповићеве биографије.

Свим наведеним ликовима Кашанин је позајмио нешто из сопственог искуства. Необјављене Кашанинове успомене на сусрете са Богданом Поповићем, помажу да разумемо пишчево полазиште у грађењу Пантулиног лика. Тако је сусрет између Коче Пантуле и Драгослава Којића у Паризу добио обрисе сусрета и упознавања самог писца са Богданом Поповићем у овом граду. Да су Кашанинови утисци о Богдану Поповићу уткани у лик Коче Пантуле потврђује поређење Кашаниновог необјављеног рукописа и делова из романа Привиђењь.

„Богдан Поповић”, рукопис: „Био сам тачан. Да не бих задоцнео и пропустио јединствену прилику да га упознам, дошао сам пет минута раније. Угледао сам га из хола где седи у трпезарији за доручком, сачекао да буде десет до десет и ушао. Пред њим је био богат енглески доручак, на који сам и против воље спустио очи пре него на професора, - био сам гладан” (РОМС, Лични фонд „Милан Кашанин”, у обради).

Привиђења: „(...) Потражите ме сутра у овом хотелу у десет до десет . (...) Ушао је у хотел у дванаест до десет и, пријављујући се портиру, дознао од овога да његова екселенција баш доручкује у малом ресторану. (...) Не очекујући да му пружи руку, Којић се обазре и ужурбано седе на столицу преко пута од професора, имајући не само њега пред очима, него и сто за који је сео. Видећи разноврсност и количину послуженог доручка, Драган Којић се обрадова што ће разговор између њих двојице трајати дуже него што се надао (Кашанин 2003: 215).

„Богдан Поповић”, рукопис: „(..) Били смо заједно чланови жирија за књижевни конкурс Удружења пријатеља уметности Цвијета Зузорић, заједно са Светиславом Петровићем и Миланом Богдановићем. 'Ја сам тачан као математика. Ја никад не грешим” (РОМС, Лични фонд „Милан Кашанин”, у обради).

Привиђења: „,- Тачно, тачно - учврсти академик Пантула наочаре и диже главу да боље види тога који сумња. - Шта год ја тврдим, то је тачно. Ја никад не грешим" (Кашанин 2003: 111).

„Богдан Поповић”, рукопис: „(...) Саветовао ми је да узмем књигу цитата. Сретнете пријатеља и одмах имате о чему да разговарате. 'Пада киша. Као што рече Сенека...' Одмах имате о чему да разговарате и одмах показујете да сте интелигентан и начитан човек” (РОМС, Лични фонд „Милан Кашанин”, у обради).

Привиђења: „Имате ли, децо, ви књигу цитата? (...) Ја вам саветујем да набавите сваки барем једну, и да је, јутром, пре него што пођете некуд, прелистате. (...) Разговор је, као што знате, најтеже почети. У томе вам је од незаменљиве помоћи књига цитата великих 
писаца. Пред излазак из куће отворићете је и запамтити из ње три различите мисли (...) На тај начин не само што нећете бити у неприлици о чему ћете почети разговор са намерником и избећи опасност да вам он прича о својим невољама, него ћете, наводећи велике писце, показати своју начитаност и интелигенцију” (Кашанин 2003: 229-230).

Не исцрпљује се само у датим наводима из рукописа и романа веза између Богдана Поповића и лика Коче Пантуле. Истоветну везу проналазимо у есеју о Богдану Поповићу из књиге Судбине и људи.

На крају, важно је видети у којој мери Кашанин дозвољава продор аутобиографског дискурса у свом књижевном опусу. Утисак је да се наведени Кашанинов став о повезаности пишчевог живота и дела односи, најпре, на доношење што свеобухватније културолошке слике једног времена, а не на пуко гомилање детаља из личног искуства. Његово инсистирање о повезаности пишчевог живота и дела настало је на основу уверења да писац најбоље и најпоузданије може да пише о свом времену, због чега је у својим романима тематизовао савремен живот. Полазећи од живих модела, Кашанин ствара јунаке који су више налик привиђењима него стварним људима, како је и нагласио у прологу свог последњег романа. Постојеће сличности само су далеки одсјаји његове биографије и биографије његових савременика. Кашанин их вешто преобликује и варира да од свега остане само дух једног времена и далека асоцијација на стварне људе. ${ }^{9}$

Дакле, може се закључити да за Кашанина биографско јесте окосница која му помаже да би осликао друштвену атмосферу у којој ће се кретати његови јунаци. Само у том смислу писац се служи сопственим искуством како би читаоцима што боље предочио време у којем његови јунаци живе, историјске околности, приватни и јавни живот. Ниво књижевне транспозиције факта у фикцију није у функцији стварања „људи од папира”. Кашанин је на суптилан начин успео да аутобиографске елементе не пружи читаоцима у експлицитној форми, него да их искористи као књижевну грађу. Другим речима, његов стваралачки поступак нимало се не разликује од стваралачког поступка писаца који су са презиром одбацивали аутобиографско у књижевности. ${ }^{10}$ Кашанин то није чинио.

\section{ЛИТЕРАТУРА}

Андрић 2000: И. Андрић, Знакови поред пута, Сремски Карловци: Каирос. Дмитријевић 2015: К. Димитријевић, Разговори са Миланом Кашанином; Београд: Catena mundi.

Кашанин 1968: М. Кашанин, Судбине и људи, Београд: Просвета.

Кашанин 1974: М. Кашанин, Сусрети и писма, Нови Сад: Матица српска.

Кашанин 1977: М. Кашанин, Случајна открића, Нови Сад: Матица српска.

\footnotetext{
9 Кашанину су и за недовршен роман „Пријатељи” као предложак за обликовање јунака послужиле стварне личности.

${ }^{10}$ Кашанин је, на пример, један од јунака Андрићеве приповетке „Дедин дневник”.
} 
Кашанин 2000: М. Кашанин, Поговор, у: Лаза Костић, Дневник, Београд: Народна књига.

Кашанин 2003²: М. Кашанин, Привиђења, Београд: Завод за уџбенике и наставна средства.

Недић 2004: М. Недић, Разговори са Миланом Кашанином, у: М. Кашанин, Изабрана дела, књ. 8, Београд: Завод за уџбенике и наставна средства.

Новаковић 1998: Ј. Новаковић, Однос према аутобиографији или 'мрско ја': Иво Андрић и француска књижевна мисао, Српска аутобиографска књижевност, Научни састанак слависта у Вукове дане, 27/1, 299-309.

Оцић 2004: Ђ. Оцић, Разговори са Кашанином, у: М. Кашанин, Изабрана дела, књ. 8, Београд: Завод за уџбенике и наставна средства.

Перишић Ђукић 2012: Ž. Đukić Perišić, Pisac i priča. Stvaralačka biografija Ive Andrića, Novi Sad: Akademska knjiga.

Тријић 2018: В. Тријић, Искуство стварности у роману Привиђења Милана Кашанина, у: Ј. Алексић, Ђ. Нешић (ур.), Зборник радова с Међународног научног скупа Кьижевни и критичарски опус Милана Каманина, Даљ, Београд: Културни и научни центар Милутин Миланковић, Институт за књижевност и уметност, 119-132.

Удовички 1982: И. Удовички, Кюижевни критичар Милан Кашанин, Београд: Институт за књижевност и уметност - Вук Караџић.

\section{Архивска грађа}

РОМС, Лични фонд „Милан Кашанин (1895-1981)”, у обради; РОМС, инв. бр. 48.081.

Zorica P. Hadžić

\section{(AUTO) BIOGRAPHICAL ELEMENTS IN THE LITERARY WORK OF MILAN} KAŠANIN

Summary

Milan Kašanin emphasized in several places that it is essential to know the life of the author in order to properly interpret his work. In such a belief, in books published after the Second World War, he often discovered fragments from his own life. This research follows the reflections of autobiographical elements in the work of Milan Kašanin. The subject of analysis are primarily the books Susreti i pisma (1974), Slučajna otkrića (1977) and the novel Priviđenja (1981). However, Kašanin, by offering fragments of the autobiography in his own literary work, subtly managed not to provide the autobiographical elements to the reader in an explicit form, but to use them as a basis for literary material. 